\title{
The Arkansas traveler's paradox: COVID-19 and the rural sociology of stupidity
}

\author{
Michael M. Bell ${ }^{1}$
}

Accepted: 25 April 2020 / Published online: 4 June 2020

C) Springer Nature B.V. 2020

A traveler from the city, wending his Model T through the hills of Arkansas, learned some rural wisdom we would do well to recall in these plagued times. Or so tells a classic bit of American folklore, which goes something like this.

\section{$* * *$}

A city slicker — a man — heads out for a country drive one fine spring day, but gets lost among the many unmarked roads of the Ozarks. After all, he had no cell phone or GPS mapping gadget built into the dashboard. (Yes, my sweet, there was such a time, not all that long ago to some of us.) He comes to a fork in the road and has no idea which way to turn. So he is forced into an unmanly act: asking directions.

He notices a farmer standing in a pasture, playing an old fiddle. The city slicker leans out of the car window and calls, "Hey farmer, which road do I take to get back to Little Rock?"

The farmer-also a man—glares from under his beat-up straw hat, pauses in his playing, and drawls, "You don't take neither of them roads. You leave them right there, if you please." He goes back to playing.

The city slicker considers this unhelpful reply, as he also considers a large puddle which he would have to cross to get to either fork. He leans out of the window again and asks, more politely this time, "Hey Mr. Farmer, could you please advise me how deep this puddle is?"

The farmer pauses his fiddling only long enough to grunt, "Waist high on a duck."

The city slicker gets out of his car to inspect the puddle for himself. Fuming, he calls out to the farmer, "There's not much difference between you and a fool, is there?"

This article is part of the Topical Collection: Agriculture, Food \& Covid-19.

Michael M. Bell

michaelbell@wisc.edu

1 University of Wisconsin-Madison, Madison, USA
“ "Bout twenty feet, I'd judge it," says the farmer, not even pausing his playing.

The city slicker is plenty exasperated now. He looks around and notices the farmer's tumbledown house on a hill above the pasture, and he demands, "I see your roof is leaking. Why don't you fix it?"

The farmer takes his fiddle from under his chin, gives the city slicker a hard stare, and answers, "Can't fix it when it's rainin', and when it ain't rainin' I don't need to.”

$* * *$

Who, then, is the fool in what I like to call the Arkansas traveler's paradox? And what does it suggest to us about this awful moment, how we got here, and how we can ensure we never face such a crisis again?

The rural insight here is not the stupidity of the farmer. The story knows that the farmer's statement is absurd. The farmer knows it too, as with all his sarcastic replies to the "city slicker," the Arkansas traveler. The farmer knows just why his roof leaks. It's not because he is stupid, as the traveler suggests. It's because he is poor.

Moreover, as the farmer implies with his scowling responses, he is poor in part because the city slicker is rich.

A commonplace of life is that a problem becomes most evident in a crisis, which is precisely the most difficult time to address it. Recognizing this dilemma, we ruefully excuse ourselves, or the powers that be, for failure to address it when the sun was shining and now once again because it's pouring. But this definition of the situation is dumb, a paradox of collective stupidity. Leaks generally start small, warning us of what is to come when a big storm hits. Moreover, although it may be uncomfortable and slippery, we actually can fix a roof while it's raining.

No, the origin of this paradox is not a cognitive lapse, a distracted brain. It's a social lapse. Why do we so often fail to address the leaks in our care for ourselves and one another? The farmer's barbed comments nail it: Because of the cruel stupidity of inequality. 
Ultimately such inequality isn't even in the Arkansas traveler's interests, if he is ever to get safely back home to the well-fed comforts of Little Rock. But to change the definition of the situation we need to change our social relations, as the Arkansas traveler ultimately discovers in the story.

$$
* * *
$$

The farmer puts the fiddle back under his chin, still sawing away at the same tune he has been playing the whole time.

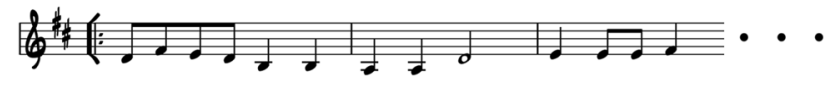

The city slicker starts to make another comment about the farmer's roof, when something else occurs to him. "Say, farmer, how come you just keep playing the first part of that tune?"

"You know the second part? I never done heard it, neither heard this tune's name."

"You bet I do. And if you loan me your fiddle, I can teach it to you. The tune's called 'Arkansas Traveler,' by the way. That's just what I am, I guess.”
The farmer comes over to the fence and hands the city slicker his fiddle, who plays the second part of the tune.

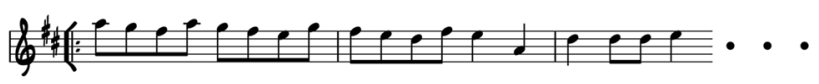

"Well I never, that's just fantastic! Why don't you come right on up to the house? We'll get you a warm bed and a square meal for the night. Invite the neighbors, too, maybe fix up a little dance, and send you on your way in the morning. Besides, it's startin' to rain."

Despite the leaks, they all get on like a house on fire.

$$
\text { *** }
$$

Which it is.

Publisher's Note Springer Nature remains neutral with regard to jurisdictional claims in published maps and institutional affiliations. 